\title{
Genetic diversity of Hepatozoon spp. in rodents from Chile
}

\author{
Diversidade genética de Hepatozoon spp. em roedores do Chile \\ Amir Salvador Alabí1; Gustavo Monti2; Carola Otth³; Paulina Sepulveda-García1; Livia Perles; \\ Rosangela Zacarias Machado4; Marcos Rogério André4; Pedro Bittencourt ${ }^{5}$; Ananda Müller ${ }^{1,5 *}$ (1) \\ ${ }^{1}$ Instituto de Ciencias Clínicas Veterinarias, Facultad de Ciencias Veterinarias, Universidad Austral de Chile, Valdivia, Chile \\ 2Insituto de Medicina Preventiva Veterinaria, Facultad de Ciencias Veterinarias, Universidad Austral de Chile, Valdivia, Chile \\ ${ }^{3}$ Instituto de Microbiologia Clínica, Facultad de Medicina, Universidad Austral de Chile, Valdivia, Chile \\ ${ }^{4}$ Departamento de Patologia, Reprodução e Saúde Única, Faculdade de Ciências Agrárias e Veterinarias - FCAV, Universidade Estadual \\ Paulista - UNESP, Jaboticabal, SP, Brasil \\ ${ }^{5}$ One Health Center for Zoonoses and Tropical Veterinary Medicine, Department of Biomedical Sciences, Ross University School of \\ Veterinary Medicine, Basseterre, Saint Kitts and Nevis, West Indies
}

How to cite: Alabí AS, Monti G, Otth C, Sepulveda-García P, Perles L, Machado RZ, et al. Genetic diversity of Hepatozoon spp. in rodents from Chile. Braz J Vet Parasitol 2021; 30(4): e012721. https://doi.org/10.1590/S1984-29612021082

\begin{abstract}
This study aimed to investigate the genetic diversity of Hepatozoon spp. in rodents from Valdivia, Chile. A total of 74 rodents (synanthropic $n=38$; wild $n=36$ ) were trapped in Valdivia. We performed conventional PCR assays for Apicomplexa organisms targeting two overlapping $18 \mathrm{~S}$ rDNA gene fragments (600 bp and $900 \mathrm{bp}$ ) followed by sequencing of selected amplicons. Hepatozoon spp. occurrence was $82.43 \%$ (61/74). Twelve sequences obtained from the $600 \mathrm{bp}$ and ten from the $900 \mathrm{bp} 18 \mathrm{~S}$ rDNA fragments were identified as Hepatozoon sp. Six sequences obtained from 18S rDNA-based overlapping PCR protocols were used for concatenated $(1,400$ bp) phylogenetic, haplotype and distance analyses. Hepatozoon spp. $18 \mathrm{~S}$ rDNA concatenated sequences from the present study were detected in Oligoryzomys longicaudatus, Rattus norvegicus, Mus musculus, and Abrothrix longipilis grouped with Hepatozoon species earlier described in rodents and reptiles from Chile and Brazil. Nucleotide polymorphism of the six $18 \mathrm{~S}$ rDNA sequences $(1,400 \mathrm{bp})$ from this study, and other Chilean sequences from rodents and rodent's ticks, showed high diversity with a total of nine Chilean haplotypes. Three haplotypes from Valdivia were identified for the first time in this study, suggesting the circulation of novel haplotypes in rodents from southern Chile.
\end{abstract}

Keywords: Apicomplexan, hepatozoonosis, rodentia, PCR, phylogenetics, South America.

\section{Resumo}

Este estudo teve como objetivo investigar a diversidade genética de Hepatozoon spp. em roedores de Valdivia, Chile. Um total de 74 roedores (sinantrópicos $n=38$; selvagens $n=36$ ) foram capturados. PCR convencional foi realizada para organismos Apicomplexa, visando dois fragmentos sobrepostos do gene $18 \mathrm{~S}$ rDNA (600 bp e 900 bp), seguida pelo sequenciamento de amplicons selecionados. A ocorrência de Hepatozoon spp. foi de 82,43\% (61/74). Doze sequências obtidas dos fragmentos de 18S rDNA de $600 \mathrm{pb}$ e dez dos fragmentos de $18 \mathrm{~S}$ rDNA de 900 pb foram identificadas como Hepatozoon sp. Seis sequências obtidas, a partir de protocolos de PCR sobrepostos, foram usadas para análises filogenéticas (1.400 bp), de haplótipos e de distância. Sequências concatenadas $18 \mathrm{~S}$ rDNA do presente estudo foram detectadas em Oligoryzomys longicaudatus, Rattus norvegicus, Mus musculus e Abrothrix longipilis e agrupadas com Hepatozoon descrito em roedores e répteis do Chile e do Brasil. A análise de polimorfismos das seis sequências deste estudo, junto com outras sequências chilenas de roedores e carrapatos de roedores, mostrou alta diversidade com um total de nove haplótipos no Chile. Três haplótipos detectados em Valdivia foram identificados pela primeira vez neste estudo, sugerindo que novos haplótipos circulam em roedores do sul do Chile.

Palavras-chave: Apicomplexa, hepatozoonose, rodentia, PCR, filogenia, América do Sul. 


\section{Introduction}

The genus Hepatozoon (Adeleorina; Hepatozoidae) comprises apicomplexan parasites that were first detected in India (Bentley, 1905). Since then, many species have been described, from various vertebrate hosts, such as mammals, birds, reptiles, and amphibians. Although not considered a primary zoonotic pathogen, zoonotic potential has been described, as Hepatozoon sp. was detected in Russian and Philippine patients (Craig, 2006; Lappin, 2010; Shuikina et al., 2004).

The life cycle of Hepatozoon spp. includes invertebrates (definitive hosts), represented by ticks, fleas, flies, mosquitoes, or lice, from which vector competence was proved, and vertebrates (intermediate hosts) (Modrý et al., 2017; Rubini et al., 2006; Lainson et al., 2003; Watkins \& Nowell, 2003). The vertebrate host is usually infected by ingestion of a hematophagous arthropod, although infection can be acquired also by intrauterine transmission or by predation (Modrý et al., 2017).

Even though Hepatozoon spp. were detected in rodents from several geographical locations, such as Europe (Criado-Fornelio et al., 2006; Laakkonen et al., 2001; Rigó et al., 2016), Africa (Harris et al., 2017; Maia et al., 2014), North America (Johnson et al., 2007, 2008a), and South America (de Sousa et al., 2017; Demoner et al., 2016; Perles et al., 2019; Wolf et al., 2016), their role as intermediate hosts for carnivore-associated Hepatozoon species has only been confirmed in the USA (Johnson et al., 2008a). For instance, Hepatozoon americanum is transmitted due to the predation of infected rabbits (Oryctolagus cuniculus) and rodents [S. hispidus, Mus musculus, and Rattus rattus] (Johnson et al., 2008a, b, 2009).

In Chile, although the presence of Hepatozoon was confirmed in rodents, marsupials, and associated ectoparasites, little is known about the genetic diversity of this group of tick-borne pathogens. Hepatozoon sp. was detected in $54.5 \%$ (6/11) of Olive gray mouse (Abrothrix olivaceus) and 50\% (2/4) of long-haired akodont (Abrothrix sanborni) sampled in Senda Darwin Biological Station and forest in Chiloé Island, southern Chile (Merino et al., 2009). Recently, Hepatozoon spp. was detected in Ixodes sp. and Ornithodoros atacamensis ticks collected from wild rodents (Phyllotis darwini) in national parks of Pan de Azúcar and Bosque Fray Jorge, in Northern Chile (Muñoz-Leal et al., 2019). Phylogenetic analysis of Hepatozoon sp. detected in ectoparasites from Chile showed its relatedness to Hepatozoon spp. detected in the marsupial Monito del monte (Dromiciops gliroides) and Olive gray mouse (A. olivaceus) from Chile (Merino et al., 2009).

This study aimed to investigate the genetic diversity of Hepatozoon spp. in wild and synanthropic rodents from the Valdivia province, southern Chile.

\section{Materials and methods}

\section{Study site}

The study was approved by the Universidad Austral de Chile (UACh) bioethics committee (Uach/1141070). The sampling for this study included four locations within the Valdivia province, Southern Chile: Corral (Arica Interior

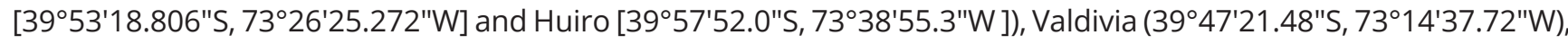

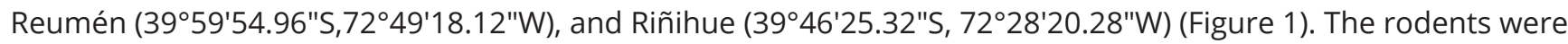
sampled by convenience for an unrelated study at UACh.

\section{Rodent trapping and sampling}

The trapping occurred from November 2016 and November 2017, on dairy farms from the Valdivia province. Traps ( $20 \mathrm{~cm} \sim 20 \mathrm{~cm} \sim 60 \mathrm{~cm}$ Tomahawk cages) were baited with oatmeal and vanilla flavoring, placed in areas where rodents were usually seen and reviewed daily, during the morning for the period of four days. Any endangered, threatened, or protected species were immediately released.

The captured rodents were euthanized in the Pathology building of the Universidad Austral de Chile (UACh). Euthanasia was performed using a lethal dose, equivalent to 5 times the anesthetic dose (inhaled Isoflurane, followed by an intraperitoneal injection of a combination of Xylazine-Ketamine) (Hedenqvist \& Hellebrekers, 2003). Each rodent's spleen was aseptically removed after euthanasia, stored and preserved in $70 \%$ Ethanol (Merck ${ }^{\odot}$, USA) at $-20^{\circ} \mathrm{C}$, until further analyses. 


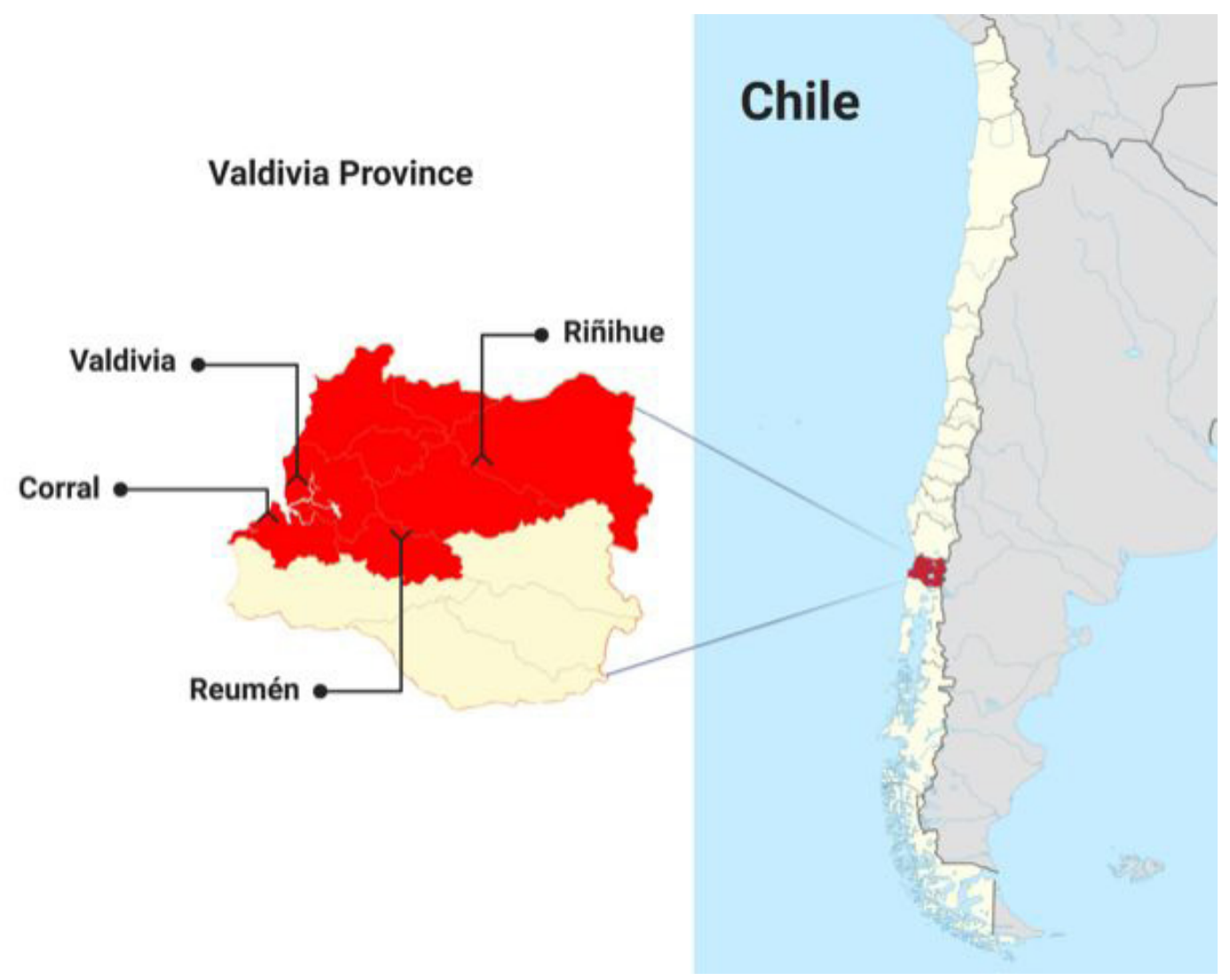

Figure 1. Rodent sampling sites within the Valdivia Province, Southern Chile.

The capture, management, and euthanasia of rodents followed the specifications of the American Society of Mammologists and the protocols and norms established by the funding agency (CONICYT, 2008). Biological protocols for dangerous material were used for carcasses disposal.

\section{Distribution of sampled rodents}

Seventy-four rodents were sampled: 35.13\% (26/74) were trapped in Corral, 8.1\% (6/74) in Valdivia, 22.97\% (17/74) in Reumén, and 33.78\% (25/74) in Riñihue. Four rodent genera were identified: 5.40\% (4/74) were represented by house mouse (Mus musculus), 21.62\% (16/74) by brown rat (Rattus norvegicus), 24.32\% (18/74) by black rat (Rattus rattus), $17.56 \%$ (13/74) by long-haired grass mouse (Abrothrix longipilis), 10.81\% (8/74) by grass mouse (Abrothrix olivaceus), $13.51 \%$ (10/74) by long-tailed pygmy rice rat (Oligoryzomys longicaudatus), and $6.75 \%$ (5/74) that were not identified on a species level, being classified as Abrothrix spp. (once it was not possible to differentiate between A. olivaceus or A. longipilis).

\section{DNA Extraction from Rodent Spleen and PCR for Mammals' endogenous gene}

The frozen rodent spleens were thawed at room temperature and $15 \mathrm{mg}$ portions were refrozen with liquid nitrogen and manually macerated with a plastic pestle. DNA extraction of the macerated spleen suspension was performed with the "Tissue DNA Kit" (E.Z.N.A. Omega BioTek ${ }^{\circledR}$, Norcross, GA, USA), as per the manufacturer's instructions (100 $\mu$ L elution). A spectrophotometer (NanoDrop ND-1000 Thermo Scientific ${ }^{\circ}$, Waltham, MA, USA) was used for measuring the DNA concentration and absorbance ratio $(260 / 280 \mathrm{~nm})$. Nuclease-free water (Thermo Scientific $^{\odot}$, USA) was used as a template to verify cross-contamination, every 20 extractions. DNA was stored at $-20^{\circ} \mathrm{C}$ before performing PCR assays.

To verify the presence of amplifiable DNA and check the integrity of the DNA template, the irbp ("interphotoreceptor retinoid-binding protein") endogenous mammalian gene was used (Ferreira et al., 2010). 


\section{Molecular detection of apicomplexan organisms}

Positive samples for the irbp gene were submitted to a conventional PCR protocol to amplify a fragment (600 bp) of the 18S rDNA of Apicomplexa organisms, as previously described (Vilcins et al., 2009). All PCR runs were performed with nuclease-free water (Thermo Scientific ${ }^{\odot}$, Waltham, MA, USA) as a negative control and Taq DNA polymerase (Life technologies ${ }^{\odot}$, Carlsbad, CA, USA) for amplification. Hepatozoon caimani DNA obtained from naturally infected crocodiles was used as a positive control (Bouer et al., 2017).

All the samples were further tested for a second $18 \mathrm{~S}$ rDNA-based PCR protocol targeting a complimentary (900 bp) fragment of Apicomplexan organisms (Perkins \& Keller, 2001), aiming at obtaining a larger portion of the $18 \mathrm{~S}$ rDNA gene (1,400 bp) for phylogenetic and haplotype analyses.

Both $600 \mathrm{bp}$ and $900 \mathrm{bp} 18 \mathrm{~S}$ rDNA amplicons showing high intensity bands in agarose gel electrophoresis were purified using "Silica Bead DNA Gel Extraction Kit" (Fermentas, São Paulo-SP), following the manufacturer's instructions, and sent to the Center of Biological Resources and Genomic Biology (CREBIO, Jaboticabal, SP, Brazil) for sequencing by Sanger's method with ABI PRISM 3700 DNA Analyzer (Applied Biosystems ${ }^{\odot}$, Foster city, CA, USA). Only sequences obtained for both overlapping 185 rDNA-based PCR protocols were used for concatenated $(1,400 \mathrm{bp})$ phylogenetic and haplotype analyses.

\section{BLAST Analysis}

Electropherograms were submitted to PhredPhrap analysis (Ewing et al., 1998), with the Phred quality score (peaks around each base call) established as higher than 20 (99\% accuracy of the base call), to determine the nucleotide composition. We performed a BLAST analysis to evaluate the identity percentage of our sequences with those deposited in the GenBank database (Altschul et al., 1990; Benson et al., 2004).

The consensus sequences were obtained by aligning the sense and antisense sequences using PhredPhrap software. Consensus sequences were submitted to GenBank under the following accession numbers MK454902/ MH594207; MK454899/MH216198; MK454898/MH216197; MK454895/MH216195; MK454896/MH216196; MK454901/MH216199.

\section{Phylogenetic analysis}

Concatenated sequences ( 1400 bp) were used for phylogenetic analysis. Initially, the best evolutionary model was selected by the program jModelTest2 (version 2.1.6) on 11 XSEDE (Santorum et al., 2014), under the Akaike Information Criterion (AIC) (Posada \& Buckley, 2004). Maximum likelihood (ML) inference was performed with the IQ-TREE webserver (Trifinopoulos et al., 2016). The phylogenetic tree was edited with Treegraph 2.0.56-381 beta (Stöver \& Müller, 2010) and cluster design was created with BioRender.com (Biorender, 2020).

\section{Haplotype analysis}

Nucleotide polymorphism analysis of $18 \mathrm{~S}$ rDNA concatenated sequences obtained in this study was performed using DnaSP v5 (Librado \& Rozas, 2009). Haplotype diversity (Hd), number of haplotypes (n), and nucleotide diversity (Pi) were analyzed to investigate the genetic diversity among Hepatozoon sequences detected in the sampled rodents (using parameters: not considered missing/gaps and considered invariable sites). Haplotype networks were generated with PopArt (Clement et al., 2002; Leigh \& Bryant, 2015). Additional haplotype analyses were performed by combining the sequences detected in this study and those previously detected in rodents and rodents' ticks from Chile (GenBank accession numbers: FJ719819, FJ719818, FJ719816, FJ719817, MH174343, MH174344, MH174345) (Merino et al., 2009; Muñoz-Leal et al., 2019). A haplotype network was constructed using the TCS Network and the PopArt software (PopART, 2020) (Clement et al., 2002; Leigh \& Bryant, 2015).

\section{Splits network analysis}

Splits tree v4.11.3 (Huson, 1998) was used to generate a phylogenetic distance network with sequences obtained from the present study and sequences from Genbank (Supplementary Table S1). Final trees and haplotype network design were created with Biorender.com (Biorender, 2020). 


\section{Results}

\section{Endogenous gene and Hepatozoon occurrence in sampled rodents}

All 74 DNA samples tested positive for the irbp gene (Mean and Standard Deviation (SD) with a DNA concentration=159.60 $\mathrm{ng} / \mu \mathrm{L} \pm 212.09 \mathrm{ng} / \mu \mathrm{L}$; mean and SD 260/280 ratio=2.12 \pm 0.21 ).

An overall proportion of $82.4 \%$ (61/74) of the rodents were positive for Hepatozoon spp. Synanthropic and wild rodents presented Hepatozoon prevalence rates of $78.94 \%$ (30/38) and $86.11 \%$ (31/36), respectively. Within the synanthropic rodents, M. musculus showed an occurrence of $4.05 \%(3 / 74), R$. norvegicus $17.56 \%(13 / 74)$ and $R$. rattus $18.91 \%(14 / 74)$ and in the wild rodents' group are included $A$. longipilis which showed an occurrence of $16.21 \%$ (12/74), A. olivaceus 10.81\% (8/74), Abrothrix spp. 2.70\% (2/74) and O. Iongicaudatus $12.16 \%$ (9/74).

\section{Sequenced samples, Blast Analysis and Genetic characterization}

Twelve $18 \mathrm{~S}$ rDNA amplicons obtained with the 600bp PCR protocol for Apicomplexan organisms (primers HepF300 and HepF900; 600 bp) presented strong band intensity and were sequenced. 18S rDNA Hepatozoon partial sequences obtained from six rodents in this study (MK454892 [M. musculus], MK454894 [R. norvegicus], MK454896 [R. norvegicus], MK454897 [M. musculus], MK454898 [R. norvegicus], MK454900 [R. norvegicus]) presented 99-100\% identity with Hepatozoon sp. detected in A. olivaceus (FJ719818) rodents from Chile (Merino et al., 2009); two sequences (MK454901 [A. longipilis], MK454903 [A. longipilis]) presented 99-100\% identity with Hepatozoon spp. detected in A. sanborni rodents from Chile (FJ719819, FJ719816) (Merino et al., 2009); two sequences (MK454893 [R. norvegicus], MK454899 [R. norvegicus]) presented 100\% identity with Hepatozoon sp. detected in Lytorhynchus diadema reptiles (KX453636) from Oman (Maia et al., 2016b); one sequence (MK454895 [M. musculus]) was 100\% identical to Hepatozoon sp. detected in the reptile Hemidactylus mabouia (KM234616) (Harris et al., 2015) from Brazil; and finally, one sequence (MK454902 [O. longicaudatus]) showed 100\% identity with Hepatozoon sp. detected in Thylamys macrurus marsupial (KX776354) from Brazil (de Sousa et al., 2017).

Ten amplicons obtained from the second Apicomplexan 18S rDNA-based PCR protocol (primers HEMO1 and HEMO2; 900 bp) presented high-intensity bands in agarose gel electrophoresis and were submitted to sequencing. Hepatozoon 18S rDNA partial sequences obtained from five rodents in this study (MH216195 [M. musculus], $\mathrm{MH} 216196$ [R. norvegicus], MH216199 [A. longipilis], MH594205 [A. olivaceus], MH594208 [A. olivaceus]) showed $100 \%$ identity with Hepatozoon sp. detected in A. olivaceus (FJ719818) and A. sanborni (FJ719819) rodents from Chile (Merino et al., 2009); three sequences (MH594204 [O. longicaudatus], MH594206 [O. longicaudatus], MH594207 [O. longicaudatus]) were 99\% identical to Hepatozoon spp. detected in Oecomys marmorae (KX776332) rodents from Brazil (de Sousa et al., 2017); finally, two sequences (MH216197 [R. norvegicus], MH216198 [R. norvegicus]) presented 99\% identity with Hepatozoon sp. detected in Tarentola deserti (KU680460) reptile from Morocco (Tomé et al., 2016).

Six sequences were obtained for both Apicomplexan $18 \mathrm{~S}$ rDNA-based PCR protocols and used for concatenated (1,400 bp) phylogenetic, haplotype and distance analyses. These concatenated sequences were: MK454902/ MH594207 detected in an O. longicaudatus; MK454899/MH216198, MK454898/MH216197, and MK454896/ MH216196 detected in R. norvegicus; MK454895/MH216195 from M. musculus; and MK454901/MH216199 from A. longipilis.

\section{Phylogenetic analysis}

According to the phylogenetic inference, five different clades were observed, two of them represented by Hepatozoon spp. (Figure 2). The major clade (green colored) contained different Hepatozoon species from avian, reptilian, amphibian, rodentia, arachnoidea and marsupialia representants, including sequences of the present study. The second and minor clade of Hepatozoon species (pink colored) was formed by different Hepatozoon spp. detected in carnivores from Canidae, Felidae, Ursidae, Procyonidae, Mustelidae families, and an Ixodidae tick. The other clades comprised Hemolivia (blue colored), Karyolysus (purple colored) and Haemogregarina (grey colored) parasites.

Concatenated sequences from this study were clustered in two different subclades with other Hepatozoon $18 \mathrm{~S}$ rDNA sequences. The first subtree contained the concatenated sequences from Valdivia, Southern Chile (MK454899/MH216198; MK454898/MH216197 [Haplotype \#2] and MK454895/MH216195 [Haplotype \#4]), along with sequences from a bandicoot (Bandicota indica) in Thailand (AB181504) and Ixodid tick 


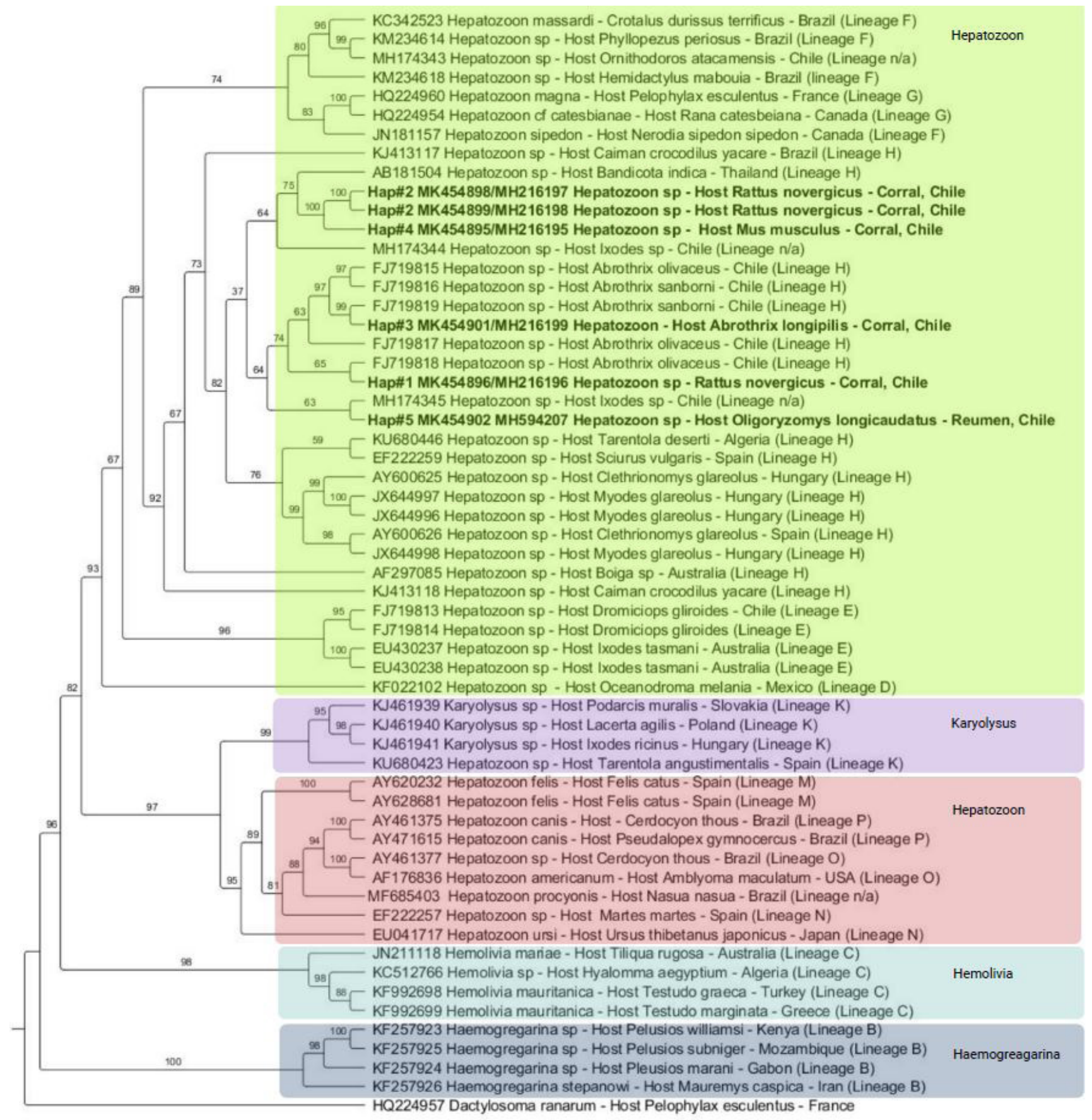

Figure 2. Phylogenetic tree based on an alignment of concatenated Hepatozoon 18S rDNA sequences, using Maximum likelihood method and TVM+I+G4+F as an evolutionary model. Numbers at nodes correspond to bootstrap. Hepatozoon sp. sequences detected in the present study are in bold letters. Dactylosoma ranarum was used as outgroups. Squared colors identify each clade.

(Ixodes sp.) from Chile (MH174344). The second subtree contained some concatenated sequences from the present study (MK454896/MH216196 [Haplotype \#1]) (MK454901/MH216199 [Haplotype \#3]) (MK454902/ MH594207 [Haplotye \# 5]) and other sequences from rodents from Chile (A. olivaceus [FJ719815, FJ719817 and FJ719818], A. sanborni [FJ719816 and FJ719819]) and an Ixodid tick (Ixodes sp.) from Chile (MH174345) (Figure 2).

Both subclades containing the concatenated sequences from Chile shared a common ancestor. Hepatozoon $18 \mathrm{~S}$ rDNA sequences from rodents in Valdivia were closely related to those previously detected in rodents and reptiles, while distant from carnivore related Hepatozoon species. 


\section{Haplotype analysis}

Nine different rodent-associated Hepatozoon 18S rDNA haplotypes were observed in Chile: while three were exclusively obtained in the Valdivia province $(\# 2, \# 4, \# 5)$ and comprised novel haplotypes, two were shared between rodents from this study and previously detected sequences from rodents in southern Chile $(\# 1, \# 3)$ (Merino et al., 2009). Finally, other four haplotypes were previously detected in rodents (\#9) and rodent-associated ticks (\#6,\#7, \#8) (Merino et al., 2009; Muñoz-Leal et al., 2019). The novel haplotypes from this study were observed in $R$. rattus and M. musculus in Corral and O. longicaudatus in Reumén.

Four haplotypes were found within the Corral locality (haplotypes \#1, \#2, \#3 and \#4): while haplotypes \#1 and \#2 were detected in R. norvegicus, haplotype \#3 was identified in A. longipilis, and haplotype \#4 in M. musculus. Additionally, Reumén showed only one haplotype (\#5). For the other localities reported in previously published studies (northern Chile) one haplotype was observed in a rodent tick from Pan de Azúcar (northern Chile) (\#7), two (haplotypes \#6 and \#8) were detected in rodents' ticks from National Park Bosque Fray Jorge (northern Chile) and three haplotypes were found in rodents from Chiloé (southern Chile) (haplotypes \#1, \#3 and \#9). The only localities that shared haplotypes were Corral (this study, southern Chile) and Chiloé (haplotypes \#1 and \#3). Table S1 summarizes the polymorphism and genetic diversity of 18S rDNA sequences of Hepatozoon species detected in rodents from Valdivia. The haplotype network is presented (Figure 3).

When analyzing the haplotype network (Figure 3) containing Hepatozoon species sequences from Chile, the nine observed haplotypes were unfrequently shared between sylvatic and synanthropic rodents or ticks. Consensus sequences (MK454902/MH594207) representing haplotype \#5 were formed by 0 . longicaudatus in the present study and rodents from Brazil (KX776336, KX776354, KU667309) comprising strictly sylvatic rodents. Haplotypes \#2 (MK454899/MH216198; MK454898/MH216197) from R. novergicus and \#4 (MK454895/ MH216195) from M. musculus consensus sequences were obtained only from synanthropic rodents and separated by only few mutational events. Haplotypes \#3 (MK454901/MH216199) and \#9 were detect strictly in Abrothix sylvatic rodents. Only one haplotype \#1 (MK454896/MH216196) was shared between a synanthropic ( $R$. novergicus) and a sylvatic rodent species ( $A$. olivaceus). Moreover, haplotypes from ticks Ixodes sp. $(\# 6, \# 8)$ and 0 . atacamensis (\#7) detected in a previous study were different from the rodents' ones.

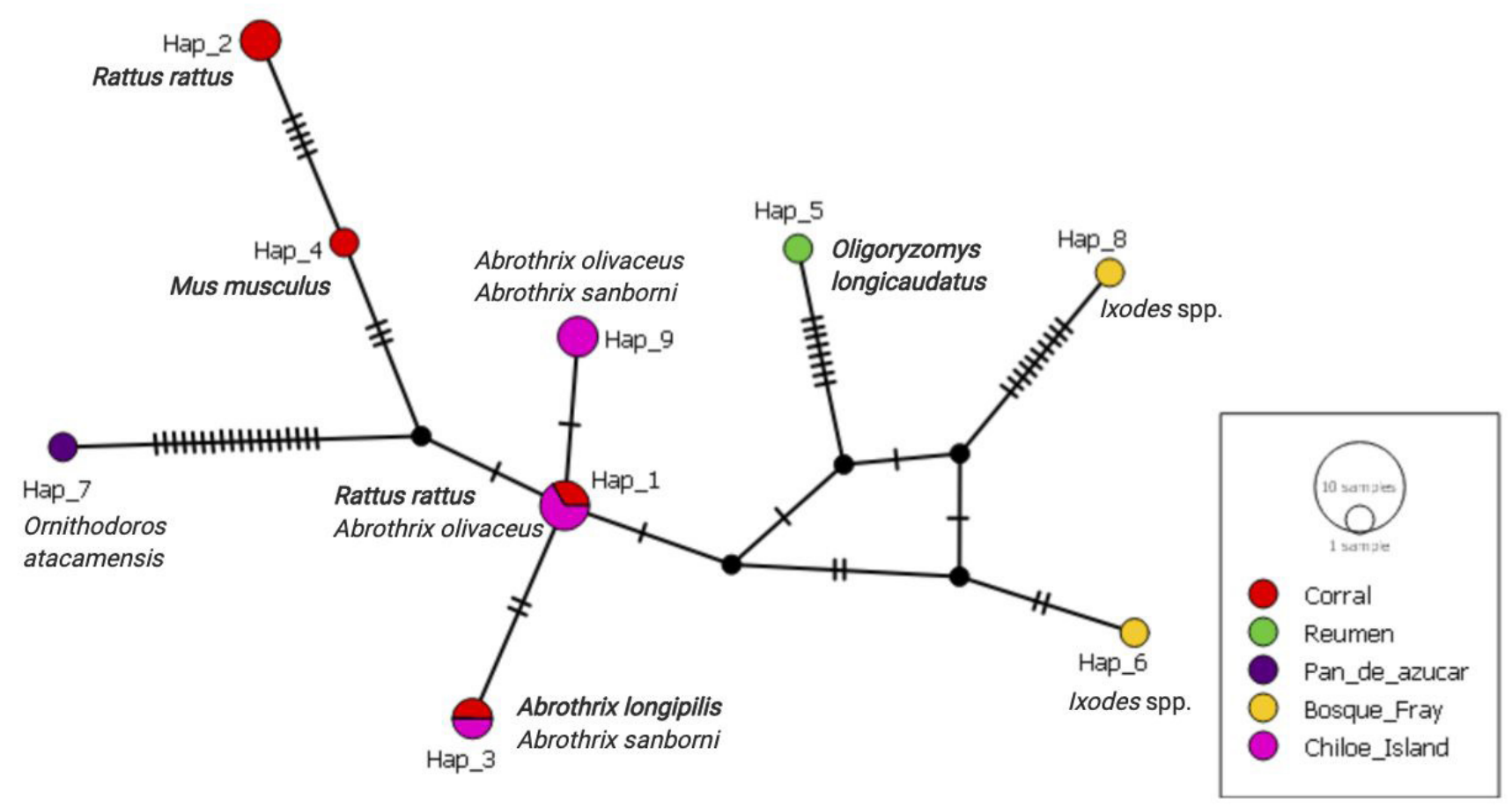

Figure 3. Hepatozoon spp. 18S rDNA haplotype network with northern (ticks from Pan de Azucar and Bosque Fray) (MuñozLeal et al., 2019) and southern Chile (rodents from Chiloe Island) (Merino et al., 2009) sequences, including the concatenated sequences from the present study in rodents from the Valdivia province (Corral, Reumen). Each dash line represents a mutational event. Present study's rodents are in bold letters. 


\section{Splits network distance analysis}

The Splits tree comprised six concatenated Hepatozoon sequences detected in rodents from the Valdivia province, along with worldwide Hepatozoon spp., Haemogregarina spp., Hemolivia spp., and Karyolysus spp. sequences (Table S1). In accordance with the Phylogenetic tree, the Splits tree positioned samples from this study separated from carnivora and subdivided into two groups. The major group contained rodents from our study (MK454902/ MH594207, MK4901/MH216199 and MK454896/MH216196) and other rodents from Chile (MH174345 MH174345, FJ719815, FJ719816, FJ719817, FJ719818 and FJ719819). The second group was comprised by sequences in rodents from this study (MK454895/MH216195, MK454899/MH216195 and MK454898/MH216197), a bandicoot from Thailand (AB181504) and an Ixodid tick from Chile (MH174344) (Figure 4).

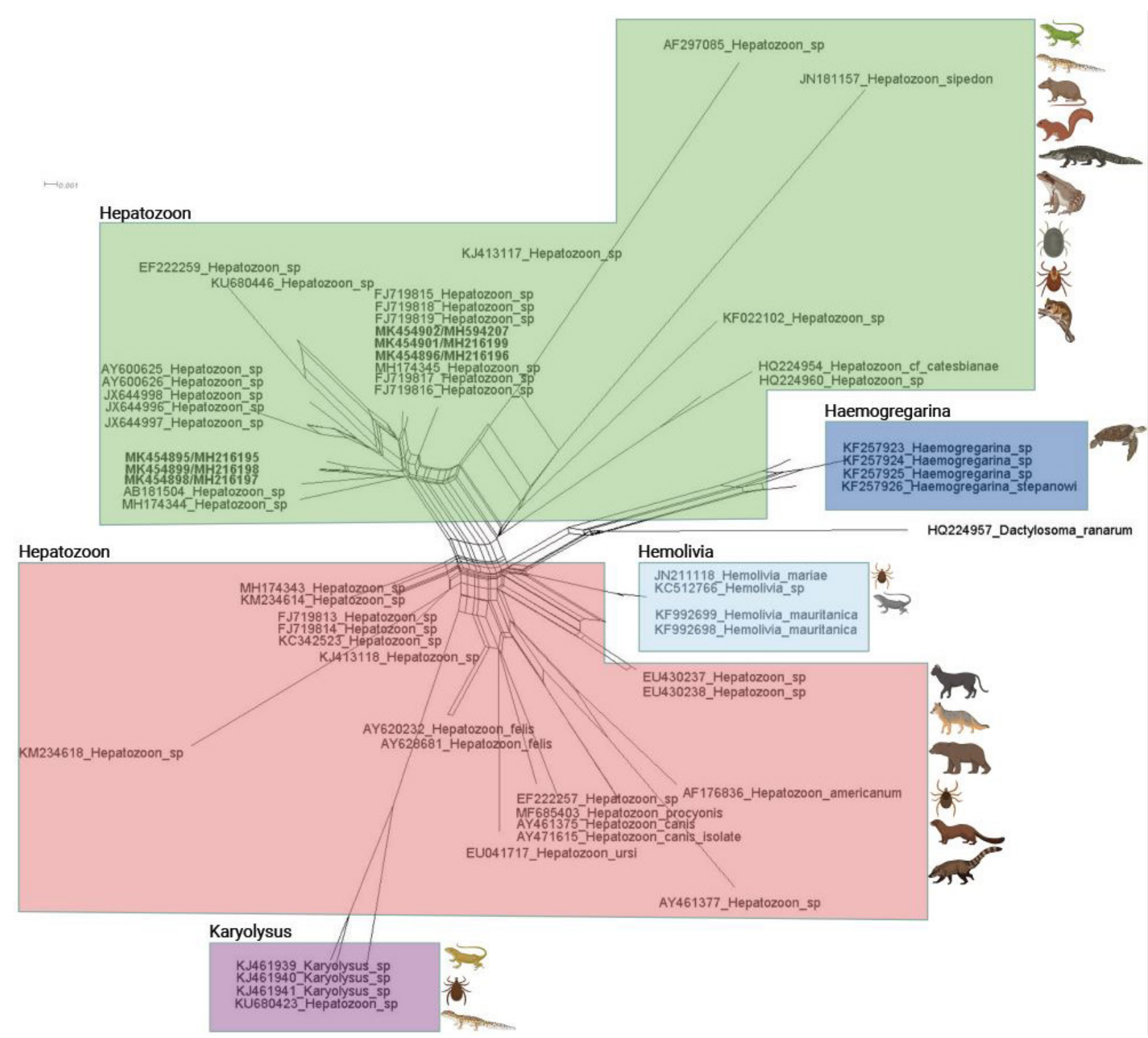

Figure 4. SplitsTree analysis generated by Neighbor-net and uncorrected P distance of Hepatozoon spp. 18S rDNA sequences obtained from rodents sampled in the present study. Present study's sequences are in bold letters.

\section{Discussion}

Previous studies described the presence of different Apicomplexan organisms in rodents worldwide, such as those from the genus Hepatozoon (Allen et al., 2011; Criado-Fornelio et al., 2006; de Sousa et al., 2017; Demoner et al., 2016; Harris et al., 2017; Johnson et al., 2008a; Laakkonen et al., 2001; Maia et al., 2014; Rigó et al., 2016; Wolf et al., 
2016), Sarcocystis (Kamani et al., 2018; Merino et al., 2008; Moustafa et al., 2017), Eimeria (Kvičerová et al., 2011; Lambert et al., 1988), Cryptosporidium (García-Livia et al., 2020; Ježková et al., 2021) and Besnoitia (Dubey et al., 2003).

Hepatozoon species are widely distributed geographically (Baneth et al., 2000; Latrofa et al., 2014), and have been detected by PCR screening in a broad variety of hosts from America, Africa, Europe, and Asia (Criado-Fornelio et al., 2006; Moustafa et al., 2017). Although Hepatozoon spp. were previously reported in rodents (A. olivaceus and $A$. sanborni) and in a marsupial (D. gliroides), both from Chiloé Island, southern Chile (Merino et al., 2009) as well as in ticks collected from rodents in northern Chile (Muñoz-Leal et al., 2019), little is known about their genetic diversity. To the best of the authors' knowledge, this is the first report of Hepatozoon spp. in rodents belonging to the following species: M. musculus, R. norvegicus, R. rattus, A. longipilis, and O. Iongicaudatus from Chile. Additionally, the nucleotide diversity and the haplotype structure of Hepatozoon species were evaluated for the first time in biological samples of rodents and rodents' ticks from Chile, using the 18S rDNA gene.

According to the phylogenetic inference of the $18 \mathrm{~S}$ rDNA gene, Hepatozoon spp. sequences detected in rodents from the Valdivia province were grouped into two clades, and separated from carnivore Hepatozoon spp. by the genus Karyolysus, corroborating previous studies (Maia et al., 2016a; Karadjian et al., 2015). The clustering patterns observed in our results were similar to those described by Maia et al. (2016a) and Karadjian et al. (2015). As such, Hepatozoon sequences were separated between carnivores (lineages M-P) and rodents, reptiles, amphibian, ticks, marsupials and birds (lineages D-H). Hepatozoon spp. sequences from synanthropic and wild rodents from the present study were positioned with other Hepatozoon sequences from lineage $\mathrm{H}$.

In South America, there are reports of Hepatozoon species in rodents from Brazil and Chile (Criado-Fornelio et al., 2006, 2009; de Sousa et al., 2017; Demoner et al., 2016; Gimenez et al.,2009; Maia et al., 2014; Merino et al., 2009; Perles et al., 2019; Wolf et al., 2016). 18S rDNA nucleotide sequences of Hepatozoon spp. obtained in this study showed high identity to those previously detected in rodents sampled in Chile (Merino et al., 2009) and Brazil (de Sousa et al., 2017).

The nucleotide polymorphism analysis of Hepatozoon concatenated 18S rDNA sequences were diverse with a high number of haplotypes $(n=5)$ among the population of sampled rodents, with some of the haplotypes $(n=3)$ only identified in the present study, suggesting that novel haplotypes occur in rodents from the Valdivia province, southern Chile. Haplotype diversity is influenced by multiple processes, such as mutation, recombination, and demography (Stumpf, 2004). The haplotype diversity of Hepatozoon spp. found in rodents in the present study $[(\mathrm{Hd})=0.933]$ was higher than the one described $[(\mathrm{Hd})=0.426]$ by Perles et al. $(2019)$ in rodents from Brazil. The former study covered a much broader geographic area, whereas the Chilean samples were collected only within the Valdivia province (southern Chile). Other studies, based on 185 rDNA sequence data, found four 18S rDNA Hepatozoon haplotypes in capybaras (Hydrochoerus hydrochaeris) from northern Brazil (de Azevedo Gomes et al., 2018), and three Hepatozoon haplotypes in rodents (Thrichomys fosteri) from the Brazilian Pantanal (de Sousa et al., 2017).

The haplotype analysis network showed a possible haplotype affinity to certain rodent groups, disregarding the geographic location. For instance, the Corral locality presented a variety of haplotypes associated with $R$. rattus (synanthropic, haplotypes \#1 and \#2), A. longipilis (wild, haplotype \#3), and M. musculus (synanthropic, haplotype \#4); while, Reumén showed only one haplotype, found in O. longicaudatus (wild, haplotype \#5). Different rodent groups (synanthropic versus sylvatic) and genera may harbor different haplotypes of Hepatozoon spp. However, Hepatozoon spp. are known to have low host specificity. Host preference for Hepatozoon haplotypes in rodents was previously described in Finland, Estonia, Russia, Poland, and Nigeria (Kamani et al., 2018; Karbowiak et al., 2005; Laakkonen et al., 2001), and thus the structure of the rodent populations may play a role in the occurrence of certain Hepatozoon spp. haplotypes. Further molecular characterization based on fast evolving genes is required to confirm this hypothesis.

Interestingly, in our study Corral was the locality with the highest number of Hepatozoon spp. haplotypes $(\mathrm{n}=3)$ in rodents. Corral also shared haplotypes with the previous study in Chiloé island (\#1 and \#3) (Merino et al., 2009), albeit geographically distant. The distribution and sharing of some haplotypes might result from the versatility of synanthropic and wild rodents, the microclimate conditions, and the topography of each sampling site (MuñozZanzi et al., 2014).

A higher number of haplotypes was observed from southern $(n=6)$ compared to northern $(n=3)$ Chile, and they did not share any Hepatozoon spp. haplotypes. This could be due to the distance and the biomes' specific characteristics from which rodents were sampled. While Pan de Azúcar (northern Chile) is characterized by coastal desert weather (Squeo et al., 1998), Chiloé (southern Chile) shares the same microclimate with Valdivia (sourhern 
Chile), which is classified as a temperate rain forest (Carmona et al., 2010; Villagran, 1991; Villagrán et al., 2004), and also shares similar elevations to the coastal region, which varies from 0-700 meters (Carmona et al., 2010; Instituto Nacional de Estadísticas, 2007). Also, different Hepatozoon spp. host adaptability (vertebrate vs invertebrate) could be related to the divergence of haplotypes, as the northern Chile samples only included rodent ticks and the southern samples included rodents. The variability in the southern samples may be due to a variety of ticks involved or other arthropods that play a role as vectors and remain unknown at the time. To the best of our knowledge there are no studies of ticks associated to rodents in Southern Chile (Valdivia or Chiloé). Ticks previously described in rodents from other regions in Chile include Ixodes spp., Ixodes abrocomae, Ixodes sigelos, Rhipicephalus sanguineus and Amblyomma tigrinum (González-Acuña \& Guglielmone, 2005; Landaeta-Aqueveque et al., 2021).

According to the Splits tree analysis, the Hepatozoon 18S rDNA sequences obtained from reptiles and rodents clustered together in a major clade. On the other hand, minor clades grouped Hepatozoon sequences from rodents and ixodid ticks reported in Chile by Muñoz-Leal et al. (2019). These findings are similar to the results reported by de Sousa et al. (2017), by Hamšíková et al. (2016) and Perles et al. (2019), and validated by Karadjian et al. (2015) and Maia et al. (2016a), confirming that Hepatozoon spp. from rodents were closely related to Hepatozoon spp. from reptiles, but distant form Hepatozoon spp. described in canids and felids. As previously reported with rodent-associated Hepatozoon from Brazil (Perles et al., 2019), Hepatozoon in rodents from Chile did not seem to participate in epidemiological cycles of Hepatozoon species infecting domestic and wild canids and felids. Those results suggest that rodents from Chile might play a role as intermediate hosts for Hepatozoon infections in reptiles and future studies should explore this hypothesis.

The results from Chile are preliminary and based on the 18S rDNA gene. Future studies in South America should explore mitochondrial genes for further Hepatozoon spp. diversity characterization, as recently described (Léveillé et al., 2019).

\section{Conclusions}

The findings of this study revealed Hepatozoon spp. in synanthropic and wild rodents in the province of Valdivia. This is the first molecular detection of Hepatozoon in M. musculus, R. norvegicus, R. rattus, A. longipilis and $O$. longicaudatus rodents from Chile. The $18 \mathrm{~S}$ rDNA sequences from this study were closely related to those previously detected in rodents and reptiles from Chile and Brazil, but distant form Hepatozoon spp. described in canids and felids. Different Hepatozoon haplotypes were observed in southern and northern Chile. Finally, Hepatozoon haplotypes from rodents sampled in Valdivia were genetically diverse, and novel haplotypes were described in rodents from southern Chile. The preliminary results from this study warrant for additional investigation on the genetic diversity of Hepatozoon spp., including in a broader population of rodents from Chile and the analysis of mitochondrial genes.

\section{References}

Allen KE, Yabsley MJ, Johnson EM, Reichard MV, Panciera RJ, Ewing SA, et al. Novel Hepatozoon in vertebrates from the Southern United States. J Parasitol 2011; 97(4): 648-653. http://dx.doi.org/10.1645/GE-2672.1. PMid:21506825.

Altschul SF, Gish W, Miller W, Myers EW, Lipman DJ. Basic local alignment search tool. J Mol Biol 1990; 215(3): 403-410. http:// dx.doi.org/10.1016/S0022-2836(05)80360-2. PMid:2231712.

Baneth G, Shkap V, Samish R, Jaffe CL. Antigenic analysis of gamonts of Hepatozoon canis purified from leukocytes. J Parasitol 2000; 86(2): 289-294. http://dx.doi.org/10.1645/0022-3395(2000)086[0289:AAOGOH]2.0.CO;2. PMid:10780547.

Benson DA, Karsch-Mizrachi I, Lipman DJ, Ostell J, Wheeler DL. GenBank: update. Nucleic Acids Res 2004;32(Database issue): D23-D26. http://dx.doi.org/10.1093/nar/gkh045. PMid:14681350.

Bentley CA. Preliminary note upon a leucocytozoan of the dog. BMJ 1905; 1(2314): 988. http://dx.doi.org/10.1136/bmj.1.2314.988. PMid:20762087.

Biorender. [online]. 2020 [cited 2020 June 2]. Available from: https://biorender.com

Bouer A, André MR, Gonçalves LR, Luzzi MC, Oliveira JP, Rodrigues AC, et al. Hepatozoon caimani in Caiman crocodilus yacare (Crocodylia, Alligatoridae) from North Pantanal, Brazil. Rev Bras Parasito/ Vet 2017; 26(3): 352-358. http://dx.doi.org/10.1590/ s1984-29612017041. PMid:28902260. 
Carmona MR, Aravena JC, Bustamante-Sánchez MA, Celis-Diez JL, Charrier A, Díaz IA, et al. Estación Biológica Senda Darwin: investigación ecológica de largo plazo en la interfase ciencia-sociedad. Rev Chil Hist Nat 2010; 83(1): 113-142. http://dx.doi. org/10.4067/S0716-078X2010000100007.

Clement M, Snell Q, Walker P, Posada D, Crandall K. TCS: Estimating Gene Genealogies Mark [online]. 2002 [cited 2019 Feb 28]. Available from: http://www.hicomb.org/papers/HICOMB2002-03.pdf

Comisión Nacional de Investigacion Cientifíca y Tecnológica - CONICYT. Manual de normas de bioseguridad [online]. 2008 [cited 2020 June 2]. Available from: https://www.conicyt.cl/fondecyt/2012/09/10/manual-de-normas-de-bioseguridad-2008/

Craig TM. Hepatozoonosis. In: Greene CE, editor. Infectious diseases of the dog and cat. 3rd ed. Philadelphia: W. B. Saunders; 2006. p. 704-705.

Criado-Fornelio A, Buling A, Casado N, Gimenez C, Ruas J, Wendt L, et al. Molecular characterization of arthropod-borne hematozoans in wild mammals from Brazil, Venezuela and Spain. Acta Parasito/ 2009; 54(3): 187-193. http://dx.doi.org/10.2478/ s11686-009-0031-5.

Criado-Fornelio A, Ruas JL, Casado N, Farias NAR, Soares MP, Müller G, et al. New molecular data on mammalian Hepatozoon species (Apicomplexa: Adeleorina) from Brazil and Spain. J Parasitol 2006; 92(1): 93-99. http://dx.doi.org/10.1645/GE-464R.1. PMid:16629322.

de Azevedo Gomes L, Moraes LA, Figueira Aguiar DC, Tavares Dias HL, Sardinha Ribeiro AS, Piram do Couto Rocha H, et al. Genetic diversity of Hepatozoon spp. in Hydrochoerus hydrochaeris and Pecari tajacu from eastern Amazon. Ticks Tick Borne Dis 2018; 9(2): 314-318. http://dx.doi.org/10.1016/j.ttbdis.2017.11.005. PMid:29174447.

de Sousa KCM, Fernandes MP, Herrera HM, Benevenute JL, Santos FM, Rocha FL, et al. Molecular detection of Hepatozoon spp. in domestic dogs and wild mammals in southern Pantanal, Brazil with implications in the transmission route. Vet Parasitol 2017; 237: 37-46. http://dx.doi.org/10.1016/j.vetpar.2017.02.023. PMid:28291601.

Demoner LC, Magro NM, da Silva MRL, de Paula Antunes JMA, Calabuig CIP, O’Dwyer LH. Hepatozoon spp. infections in wild rodents in an area of endemic canine hepatozoonosis in southeastern Brazil. Ticks Tick Borne Dis 2016; 7(5): 859-864. http:// dx.doi.org/10.1016/j.ttbdis.2016.04.002. PMid:27091081.

Dubey JP, Sreekumar C, Rosenthal BM, Lindsay DS, Grisard EC, Vitor RWA. Biological and molecular characterization of Besnoitia akodoni n. sp. (Protozoa: Apicomplexa) from the rodent Akodon montensis in Brazil. Parassitologia 2003; 45(2): 61-70. PMid:15266998.

Ewing B, Hillier L, Wendl MC, Green P. Base-calling of automated sequencer traces using Phred. I. Accuracy assessment. Genome Res 1998; 8(3): 175-185. http://dx.doi.org/10.1101/gr.8.3.175. PMid:9521921.

Ferreira EC, Gontijo CM, Cruz I, Melo MN, Silva AM. Alternative PCR protocol using a single prier set for assessing DNA quality in several tissues from a large variety of mammalian species living in areas endemic for leishmaniasis. Mem Inst Oswaldo Cruz 2010; 105(7): 895-898. http://dx.doi.org/10.1590/S0074-02762010000700009. PMid:21120359.

García-Livia K, Martín-Alonso A, Foronda P. Diversity of Cryptosporidium spp. In wild rodents from the Canary Islands, Spain. Parasit Vectors 2020; 13(1): 445. http://dx.doi.org/10.1186/s13071-020-04330-9. PMid:32887646.

Gimenez C, Casado N, Criado-Fornelio Á, de Miguel FÁ, Dominguez-Peñafiel G. A molecular survey of Piroplasmida and Hepatozoon isolated from domestic and wild animals in Burgos (northern Spain). Vet Parasitol 2009; 162(1-2): 147-150. http:// dx.doi.org/10.1016/j.vetpar.2009.02.021. PMid:19297099.

González-Acuña D, Guglielmone AA. Ticks (Acari: Ixodoidea: Argasidae, Ixodidae) of Chile. Exp Appl Acarol 2005; 35(1-2): $147-163$. http://dx.doi.org/10.1007/s10493-004-1988-2. PMid:15777007.

Hamšíková Z, Silaghi C, Rudolf I, Venclíková K, Mahríková L, Slovák M, et al. Molecular detection and phylogenetic analysis of Hepatozoon spp. in questing /xodes ricinus ticks and rodents from Slovakia and Czech Republic. Parasitol Res 2016; 115(10): 38973904. http://dx.doi.org/10.1007/s00436-016-5156-5. PMid:27245074.

Harris DJ, Borges-Nojosa DM, Maia JP. Prevalence and diversity of Hepatozoon in native and exotic geckos from Brazil.J Parasitol 2015; 101(1): 80-85. http://dx.doi.org/10.1645/14-522.1. PMid:25169765.

Harris DJ, Pereira A, Halajian A, Luus-Powell WJ, Kunutu KD. Screening for Hepatozoon parasites in gerbils and potential predators in South Africa. J S Afr Vet Assoc 2017; 88(0): e1-e4. http://dx.doi.org/10.4102/jsava.v88i0.1339. PMid:28235289.

Hedenqvist P, Hellebrekers L. Laboratory animal analgesia, anesthesia, and euthanasia. In: Hau J, Van Gerald H, editors. Handbook of laboratory animal science. 2nd ed. Washington: CRC Press; 2003. p. 413-455.

Huson DH. SplitsTree: analyzing and visualizing evolutionary data. Bioinformatics 1998; 14(1): 68-73. http://dx.doi.org/10.1093/ bioinformatics/14.1.68. PMid:9520503. 
Instituto Nacional de Estadísticas. División Político-administrativa y censal [online]. 2007 [cited 2021 Aug 22]. Available from: https:// web.archive.org/web/20090325004406/https://www.ine.cl/canales/chile_estadistico/territorio/division_politico_administrativa/ pdf/dpa_completa.pdf

Ježková J, Prediger J, Holubová N, Sak B, Konečný R, Feng Y, et al. Cryptosporidium ratti n. sp. (Apicomplexa: Cryptosporidiidae) and genetic diversity of Cryptosporidium spp. In brown rats (Rattus norvegicus) in the Czech Republic. Parasitology 2021; 148(1): 84-97. http://dx.doi.org/10.1017/S0031182020001833. PMid:32981543.

Johnson EM, Allen KE, Breshears MA, Panciera RJ, Little SE, Ewing SA. Experimental transmission of Hepatozoon americanum to rodents. Vet Parasitol 2008a; 151(2-4): 164-169. http://dx.doi.org/10.1016/j.vetpar.2007.10.017. PMid:18055118.

Johnson EM, Allen KE, Panciera RJ, Ewing SA, Little SE, Reichard MV. Field survey of rodents for Hepatozoon infections in an endemic focus of American canine hepatozoonosis. Vet Parasitol 2007; 150(1-2): 27-32. http://dx.doi.org/10.1016/j.vetpar.2007.08.050. PMid:17942230.

Johnson EM, Allen KE, Panciera RJ, Ewing SA, Little SE. Experimental transmission of Hepatozoon americanum to New Zealand White rabbits (Oryctolagus cuniculus) and infectivity of cystozoites for a dog. Vet Parasitol 2009; 164(2-4): 162-166. http://dx.doi. org/10.1016/j.vetpar.2009.05.028. PMid:19559533.

Johnson EM, Allen KE, Panciera RJ, Little SE, Ewing SA. Infectivity of Hepatozoon americanum cystozoites for a dog. Vet Parasitol 2008b; 154(1-2): 148-150. http://dx.doi.org/10.1016/j.vetpar.2008.02.026. PMid:18387744.

Kamani J, Harrus S, Nachum-Biala Y, Gutiérrez R, Mumcuoglu KY, Baneth G. Prevalence of Hepatozoon and Sarcocystis spp. in rodents and their ectoparasites in Nigeria. Acta Trop 2018; 187: 124-128. http://dx.doi.org/10.1016/j.actatropica.2018.07.028. PMid:30071191.

Karadjian G, Chavatte J-M, Landau I. Systematic revision of the adeleid haemogregarines, with creation of Bartazoon n. g., reassignment of Hepatozoon argantis Garnham, 1954 to Hemolivia, and molecular data on Hemolivia stellata. Parasite 2015; 22: 31. http://dx.doi.org/10.1051/parasite/2015031. PMid:26551414.

Karbowiak G, Rychlik L, Nowakowski W, Wita I. Natural infections of small mammals with blood parasites on the borderland of boreal and temperate forest zones. Acta Theriol (Warsz) 2005; 50(1): 31-42. http://dx.doi.org/10.1007/BF03192616.

Kvičerová J, Mikeš V, Hypša V. Third lineage of rodent eimerians: Morphology, phylogeny and re-description of Eimeria myoxi (Apicomplexa: Eimeriidae) from Eliomys quercinus (Rodentia: Gliridae). Parasitology 2011; 138(10): 1217-1223. http://dx.doi. org/10.1017/S0031182011001107. PMid:21810299.

Laakkonen J, Sukura A, Oksanen A, Henttonen H, Soveri T. Haemogregarines of the genus Hepatozoon (Apicomplexa: Adeleina) in rodents from northern Europe. Folia Parasitol (Praha) 2001; 48(4): 263-267. http://dx.doi.org/10.14411/fp.2001.043. PMid:11817449.

Lainson R, Paperna I, Naiff RD. Development of Hepatozoon caimani (Carini, 1909) Pessôa, De Biasi \& De Souza, 1972 in the Caiman Caiman c. crocodilus, the frog Rana catesbeiana and the mosquito Culex fatigans. Mem Inst Oswaldo Cruz 2003; 98(1): 103113. http://dx.doi.org/10.1590/S0074-02762003000100014. PMid:12700868.

Lambert CR, Gardner SL, Duszynski DW. Coccidia (Apicomplexa: Eimeriidae) from the subterranean rodent Ctenomys opimus Wagner (Ctenomyidae) from Bolivia, South America. J Parasitol 1988; 74(6): 1018-1022. http://dx.doi.org/10.2307/3282226. PMid:3193323.

Landaeta-Aqueveque C, Moreno Salas L, Henríquez A, Silva-de la Fuente MC, González-Acuña D. Parasites of native and invasive rodents in Chile: ecological and human health needs. Front Vet Sci 2021; 8: 643742. http://dx.doi.org/10.3389/fvets.2021.643742. PMid:33644158.

Lappin MR. Update on the diagnosis and management of Hepatozoon spp infections in dogs in the United States. Top Companion Anim Med 2010; 25(3): 142-144. http://dx.doi.org/10.1053/j.tcam.2010.07.004. PMid:20937496.

Latrofa MS, Dantas-Torres F, Giannelli A, Otranto D. Molecular detection of tick-borne pathogens in Rhipicephalus sanguineus group ticks. Ticks Tick Borne Dis 2014; 5(6): 943-946. http://dx.doi.org/10.1016/j.ttbdis.2014.07.014. PMid:25113982.

Leigh JW, Bryant D. POPART : full-feature software for haplotype network construction. Methods Ecol Evol 2015; 6(9): 1110-1116. http://dx.doi.org/10.1111/2041-210X.12410.

Léveillé AN, Baneth G, Barta JR. Next generation sequencing from Hepatozoon canis (Apicomplexa: Coccidia: Adeleorina): Complete apicoplast genome and multiple mitochondrion-associated sequences. Int J Parasitol 2019; 49(5): 375-387. http:// dx.doi.org/10.1016/j.ijpara.2018.12.001. PMid:30790556.

Librado P, Rozas J. DnaSP v5: a software for comprehensive analysis of DNA polymorphism data. Bioinformatics 2009; 25(11): 1451-1452. http://dx.doi.org/10.1093/bioinformatics/btp187. PMid:19346325.

Maia JP, Álvares F, Boratyński Z, Brito JC, Leite JV, Harris DJ. Molecular assessment of Hepatozoon (Apicomplexa: Adeleorina) infections in wild canids and rodents from North africa, with implications for transmission dynamics across taxonomic groups. J Wildl Dis 2014; 50(4): 837-848. http://dx.doi.org/10.7589/2013-10-280. PMid:25050803. 
Maia JP, Carranza S, Harris DJ. Comments on the systematic revision of Adeleid Haemogregarines: are more data needed? J Parasitol 2016a; 102(5): 549-552. http://dx.doi.org/10.1645/15-930. PMid:27385057.

Maia JP, Harris DJ, Carranza S, Goméz-Díaz E. Assessing the diversity, host-specificity and infection patterns of apicomplexan parasites in reptiles from Oman, Arabia. Parasitology 2016b; 143(13): 1730-1747. http://dx.doi.org/10.1017/S0031182016001372. PMid:27609411.

Merino S, Vásquez RA, Martínez J, Celis-Diez JL, Gutiérrez-Jiménez L, Ippi S, et al. Molecular characterization of an ancient Hepatozoon species parasitizing the 'living fossil' marsupial 'Monito del Monte' Dromiciops gliroides from Chile. Biol J Linn Soc Lond 2009; 98(3): 568-576. http://dx.doi.org/10.1111/j.1095-8312.2009.01302.x.

Merino S, Vásquez RA, MartínezJ, Celis-Diez JL, Martínez-De La Puente J, Marín-Vial P, et al. A sarcocystid misidentified as Hepatozoon didelphydis: molecular data from a parasitic infection in the blood of the southern mouse opossum (Thylamys elegans) from Chile. J Eukaryot Microbio/ 2008; 55(6): 536-540. http://dx.doi.org/10.1111/j.1550-7408.2008.00358.x. PMid:19120800.

Modrý D, Beck R, Hrazdilová K, Baneth G. A review of methods for detection of Hepatozoon infection in carnivores and arthropod vectors. Vector Borne Zoonotic Dis 2017; 17(1): 66-72. http://dx.doi.org/10.1089/vbz.2016.1963. PMid:28055571.

Moustafa MAM, Shimozuru M, Mohamed W, Taylor KR, Nakao R, Sashika M, et al. First molecular detection and characterization of Hepatozoon and Sarcocystis spp. in field mice and voles from Japan. Parasitol Res 2017; 116(8): 2321-2325. https://doi.org/10.1007/ s00436-017-5505-z.

Muñoz-Leal S, Lopes MG, Marcili A, Martins TF, González-Acuña D, Labruna MB. Anaplasmataceae, Borrelia and Hepatozoon agents in ticks (Acari: Argasidae, Ixodidae) from Chile. Acta Trop 2019; 192: 91-103. http://dx.doi.org/10.1016/j.actatropica.2019.02.002. PMid:30735640.

Muñoz-Zanzi C, Mason M, Encina C, Gonzalez M, Berg S. Household characteristics associated with rodent presence and Leptospira infection in rural and urban communities from Southern Chile. Am J Trop Med Hyg 2014; 90(3): 497-506. http://dx.doi.org/10.4269/ ajtmh.13-0334. PMid:24445209.

Perkins SL, Keller AK. Phylogeny of nuclear small subunit rRNA genes of hemogregarines amplified with specific primers.J Parasitol 2001; 87(4): 870-876. http://dx.doi.org/10.1645/0022-3395(2001)087[0870:PONSSR]2.0.CO;2. PMid:11534653.

Perles L, Roque ALR, D'Andrea PS, Lemos ERS, Santos AF, Morales AC, et al. Genetic diversity of Hepatozoon spp. in rodents from Brazil. Sci Rep 2019; 9(1): 10122. http://dx.doi.org/10.1038/s41598-019-46662-2. PMid:31300712.

PopART. [online]. 2020 [cited 2020 Jun 2]. Available from: http://popart.otago.ac.nz

Posada D, Buckley TR. Model selection and model averaging in phylogenetics: advantages of akaike information criterion and bayesian approaches over likelihood ratio tests. Syst Biol 2004; 53(5): 793-808. http://dx.doi.org/10.1080/10635150490522304. PMid:15545256.

Rigó K, Majoros G, Szekeres S, Molnár I, Jablonszky M, Majláthová V, et al. Identification of Hepatozoon erhardovae Krampitz, 1964 from bank voles (Myodes glareolus) and fleas in Southern Hungary. Parasitol Res 2016; 115(6): 2409-2413. http://dx.doi. org/10.1007/s00436-016-4992-7. PMid:27003406.

Rubini AS, Dos Santos Paduan K, Perez RR, Ribolla PEM, O'Dwyer LH. Molecular characterization of feline Hepatozoon species from Brazil. Vet Parasitol 2006; 137(1-2): 168-171. http://dx.doi.org/10.1016/j.vetpar.2005.12.008. PMid:16448756

Santorum JM, Darriba D, Taboada GL, Posada D. jmodeltest.org: selection of nucleotide substitution models on the cloud. Bioinformatics 2014; 30(9): 1310-1311. http://dx.doi.org/10.1093/bioinformatics/btu032. PMid:24451621.

Shulkina EE, Beľer TV, Sergiev VP, lastrebova RI. [Detection of hemogregarin of the genus Hepatozoon in patients in Russia]. Med Parazitol (Mosk) 2004; (4): 3-6. PMID: 15689126.

Squeo FA, Cavieres LA, Arancio G, Novoa JE, Matthei O, Marticorena C, et al. Biodiversidad de la flora vascular en la Región de Antofagasta, Chile. Rev Chil Hist Nat 1998; 71: 571-591.

Stöver BC, Müller KF. TreeGraph 2: combining and visualizing evidence from different phylogenetic analyses. BMC Bioinformatics 2010; 11(1): 7. http://dx.doi.org/10.1186/1471-2105-11-7. PMid:20051126.

Stumpf MPH. Haplotype diversity and SNP frequency dependence in the description of genetic variation. Eur J Hum Genet 2004; 12(6): 469-477. http://dx.doi.org/10.1038/sj.ejhg.5201179. PMid:15026785.

Tomé B, Rato C, Harris DJ, Perera A. High diversity of Hepatozoon spp. in Geckos of the Genus Tarentola. J Parasitol 2016; 102(4): 476-480. http://dx.doi.org/10.1645/15-908. PMid:26835601.

Trifinopoulos J, Nguyen L-T, von Haeseler A, Minh BQ. W-IQ-TREE: a fast online phylogenetic tool for maximum likelihood analysis. Nucleic Acids Res 2016; 44(W1): W232-W235. http://dx.doi.org/10.1093/nar/gkw256. PMid:27084950.

Vilcins I, Ujvari B, Old JM, Deane E. Molecular and morphological description of a Hepatozoon species in reptiles and their ticks in the Northern Territory, Australia. J Parasitol 2009; 95(2): 434-442. http://dx.doi.org/10.1645/GE-1725.1. PMid:18710299. 
Villagrán C, Armesto J, Hinojosa LF, Cuvertino J, Pérez C, Medina C. El enigmático origen del bosque relicto de Fray Jorge. In: Squeo FA, Gutierrez J, Hernández IR. Historia natural del Parque Nacional Bosqu Fray Jorge. La Serena: Universidad de La Serena; 2004. p. 6-10.

Villagran C. Historia de los bosques templados del sur de Chile durante el Tardiglacial y Postglacial. Rev Chil Hist Nat 1991; 64: 447-460.

Watkins BM, Nowell F. Hepatozoon griseisciuri in grey squirrels (Sciurus carolinensis): changes of blood leucocyte numbers resulting from infection. Parasitology 2003; 127(Pt 2): 115-120. http://dx.doi.org/10.1017/S0031182003003378. PMid:12954012.

Wolf RW, Aragona M, Muñoz-Leal S, Pinto LB, Melo ALT, Braga IA, et al. Novel Babesia and Hepatozoon agents infecting non-volant small mammals in the Brazilian Pantanal, with the first record of the tick Ornithodoros guaporensis in Brazil. Ticks Tick Borne Dis 2016; 7(3): 449-456. http://dx.doi.org/10.1016/j.ttbdis.2016.01.005. PMid:26782931. 
Hepatozoon spp. in rodents

\section{Supplementary Material}

Supplementary material accompanies this paper.

Supplementary Table S1. Phylogenetic and Splitstree analyses sequences.

This material is available as part of the online article from https://www.scielo.br/j/RBPV 